\title{
Studies of New Multistory House Electrical Supply Load and Determination Methods Update
}

\author{
Martins Budahs, JSC Distribution Network, Edvins Vanzovichs, Riga Technical University, \\ Mareks Zviedritis, JSC Sadales tikls
}

\begin{abstract}
A large amount of work has devoted to electric supply system load determination. Most of the load calculation methods and values of the appropriate factors were found many years ago and are outdated, for example, electric supply system for new many dwelling houses. At this time, there is changed not only value of loads but also its character - thus leaving the impact on the calculation methodology and factors values.

Employers of Latvenergo Distribution Network are realized wide range of load inspection in more then 24 commercial buildings and dwelling houses over two years. The results are presented in the form of official instruction. This paper is continuing the ongoing theme and dedicating improving possibilities of the calculation methodology. Particular attention has paid to existing methods of load calculation, physical interpretation of factors and possible character changes in the range.
\end{abstract}

The method is designed for design engineers and engineering staff, working with the maintenance and control of apartment buildings.

The methodology is not applicable in buildings with electric heating and hot water.

Keywords - electric power supply, electric load, protection devices

\section{INTRODUCTION}

A large amount of work has devoted to calculation of electric load [1, 2, 3]. But most of these load calculation methods and values of appropriate factors were found more then 20 years ago and are outdated, e.g., in electric power supply of many-storied dwelling houses. At this time, there is changed not only value of electric load, but also character of it, thus leaving the impact on the calculation methodology and values of load factors. Load calculation is usually connected not only with load values, but also with character of it, therefore leaving the impact on the calculation methodology. Electric load calculation normally associates with electric power supply components: selection of conductors and protection devices $[4,5]$, which will be discussed in this paper.

Employers of Latvenergo Distribution Networks are realized wide range of inspection in more then 24 manystoried commercial buildings and dwelling houses over the years. The results are presented in a form of official instruction [6]. Since this instruction does not show a recommendation connecting with existing calculation methods of electric load, physical interpretation of rated factors and possible changes in the range, then it is more complicated under stable. These problems are tried to solve in [7]. This paper continues mentioned theme and dedicated to further improvement of methodology.

\section{II.EVALUATION OF CALCULATED LOAD METHODS}

Further there is discussed evaluation and application areas of calculated load methods. Widespread used methods in designing are [1]:

- the adjusted diagrams method;

- the demand factor method;

- the specific electric power consumption method per production unit;

- the specific electric load method per area unit, usually $\mathrm{m}^{2}$.

In the table 1 there are shown these methods application areas, where they are used mostly. In the initial steps mostly there are used approximate methods, but in the last steps exact methods, as well as various methods are used in different areas. After evaluation of these areas, sometimes these methods are overlap between methods, which are illustrated in table I.

TABLE I

CALCULATED LOAD METHODS AND THEIRAPLICATION

\begin{tabular}{|c|c|c|c|c|}
\hline 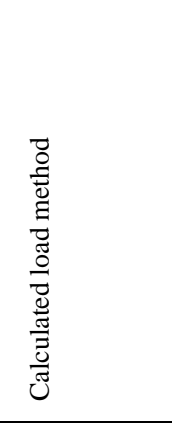 & 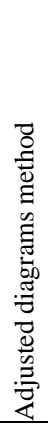 & 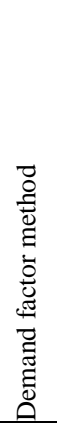 & 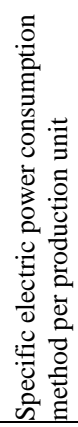 & 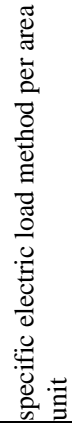 \\
\hline & 1 & 2 & 3 & 4 \\
\hline $\begin{array}{l}\text { Initial design } \\
\text { steps }\end{array}$ & & $\mathrm{x}$ & $\mathrm{x}$ & $\mathrm{x}$ \\
\hline $\begin{array}{l}\text { Last design } \\
\text { steps }\end{array}$ & $\mathrm{x}$ & $\mathrm{x}$ & & $\mathrm{x}$ \\
\hline $\begin{array}{l}\text { Industrial } \\
\text { companies }\end{array}$ & $\mathrm{x}$ & $\mathrm{x}$ & $\mathrm{x}$ & $\mathrm{x}$ \\
\hline $\begin{array}{l}\text { Agricultural } \\
\text { companies }\end{array}$ & & $\mathrm{x}$ & & \\
\hline Utilities & & $\mathrm{x}$ & & $\mathrm{x}$ \\
\hline
\end{tabular}

Now calculated load estimation will consider for 3 types of buildings categories:

- many-storied dwelling houses (4 and more apartments);

- many-storied commercial buildings; 
- many-storied dwelling houses with offices and/or shops in the ground floors.

Load calculation for all 3 types of building categories is based on measurements, taken every half an hour both in separate apartments (offices), and in income lines.

\section{MANY-STORIED DWELLING HOUSES}

\section{A. Approximate calculation}

Loads inspection had been made by load groups depending on apartment required load $\boldsymbol{P}_{\text {piet..dz., }}$, which in fact is strongly linked to rated current of the apartment main protection device, in three phase case it will be

$$
P_{\text {piet.dz. }}=\sqrt{3} \cdot I_{a . d z .} \cdot U_{n o m .} \cdot \cos (\varphi)
$$

where $\boldsymbol{I}_{\boldsymbol{a} . \boldsymbol{d} z}$. - rated current of the apartment main protection device;

$\mathrm{U}_{\text {nom. }}$ - rated voltage;

$\cos \varphi$ - power factor.

In calculation $\cos \varphi$ is supposed 0,929 .

If there is single phase incoming line, then respectively should replaced $\sqrt{3} \cdot U_{\text {nom. }} \rightarrow U_{\text {nom.faze }}$.

Approximate average apartment $\mathrm{P}_{\text {vid..dz }}$ and calculated load $P_{\text {max.dz. }}$ data, if sum of apartments $n_{d z}$ is more then 40 , are given in table II.

TABLE II

APPROXIMATED ESTIMATED VALUES OF APARTMETS CALCULATED LOAD

\begin{tabular}{|c|c|c|c|c|}
\hline 1 & 2 & 3 & 4 & 5 \\
\hline$I_{a . d z, \mathrm{~A}}$ & 16 & 20 & 25 & 32 \\
\hline$P_{\text {piet.dz, } \mathrm{kW} / \mathrm{dz} .}$ & 10.3 & 12.9 & 16.1 & 20.6 \\
\hline$n_{d z .}$ & $\geq 40$ & $\geq 40$ & $\geq 40$ & $\geq 40$ \\
\hline$P_{\text {vid.dz, }} \mathrm{kW} / \mathrm{dz}$. & 1.9 & 2.4 & 2.8 & 3.5 \\
\hline$P_{\text {max.dz., }} \mathrm{kW} / \mathrm{dz}$. & 2.3 & 2.8 & 3.2 & 3.9 \\
\hline
\end{tabular}

In this case incoming calculated load, considering that, $P_{\max . d z .} \rightarrow P_{\text {vid.dz. }}$, approximately can be determinate as

$$
P_{\max . i e v .} \approx P_{\max . d z .} \cdot n_{d z} .
$$

In any case, should be taken in an account, that calculated load is not less then average

$$
P_{\max . i e v .} \geq P_{v i d . d z .} \cdot n_{d z}
$$

\section{B. Exact calculation}

For accurately determination of incoming calculated load, there should be taken into an account apartment's main protection devices selection features. According to [4, 5] current of protection device has to ensure two following diversities

$I_{a . d z .} \geq I_{\max . d z .}$,

$I_{a . d z .} \geq \frac{I_{\text {gal.dz. }}}{K_{\text {parsl. }}}$,

where $\boldsymbol{I}_{\text {max.dz. }}$ - apartment calculated current;

$\mathrm{I}_{\text {gal.dz. }}$ - peak load (run-up load);

$\mathrm{k}_{\text {parsl. }}$ - overload factor, which depending on fuses runup conditions normally is accepted in range of 1,6 2,5 .

Testing of circuit breakers is often not made at all, assuming that thermal release time-current characteristic of protection device provides 5-6 times run-up current for 8-10 seconds without any tripping.

Because of significant character changes of apartments load, such approach is incorrect. Character changes of peak load, e.g., washing machines, working in reverse condition with multiple running-up etc. For thermal release of circuit breakers, which requires cooling time 5-6 minutes, there is not enough time. In fact, overload factor has a tendency to 1 .

For estimation of incoming calculated load, based on (5), value of peak load can be written through average load

$I_{\text {gal.dz. }} \approx K_{\text {gal.dz. }} \cdot I_{\text {vid.dz. }}$.

Let's assume till $20 \%$ reserve, in equation (5) diversity sign can be replaced with an equal sign, which together with (6) gives

$I_{\text {vid.dz. }}=\frac{K_{\text {parsl. }}}{K_{\text {gal.dz. }}} \cdot I_{a . d z .}$.

From (7) with analogy as is (1) is obtained

$P_{\text {vid.dz. }}=\sqrt{3} \cdot I_{\text {vid.dz. }} \cdot U_{\text {nom. }} \cdot \cos (\varphi)$.

The average sum load for incoming lines will be 


$$
P_{\text {vid.iev. }}=P_{v i d . d z .} \cdot n_{d z} \cdot
$$

According to the adjusted diagrams method [1] average and calculated load for incoming lines by (10), where (9) is multiplied by $\boldsymbol{K}_{\text {max.iev. }}$ - load diagram diversity maximum factor

$P_{\text {max. } . e v .}=\frac{K_{\text {max.iev. }} \cdot K_{\text {parsl. }}}{K_{\text {gal.dz. }}} \cdot P_{\text {pie.dz. }} \cdot n_{d z .}=$

$=g \cdot P_{\text {pie.dz. }} \cdot n_{d z} \cdot$

As shown, load simultaneous factor "g" is directly proportional to overload factor (close to 1), maximum factor, which according to research is changing from 1 to 2 , and inverse proportional to peak load factor.

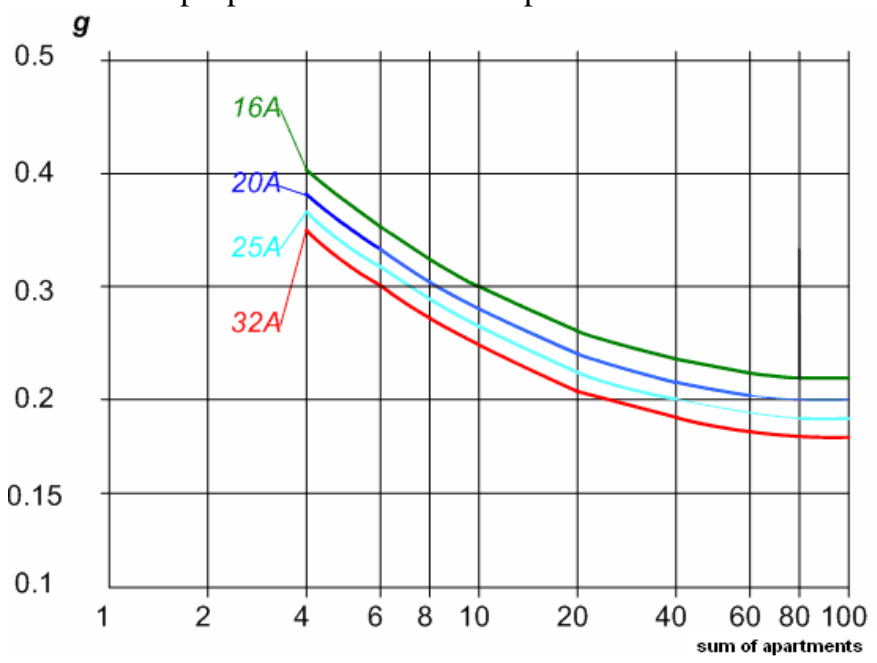

Fig. 1. The maximum simultaneous load factor of dwelling houses (three phase's incoming line with rated current from 16 to $32 \mathrm{~A}$

If its value is 5 , then inverse value $-0,2$, as evidenced by experiments. But all average and calculated load inspections give possibility to get value of "g" directly.

These values for dwelling houses with three phases $16-$ $32 \mathrm{~A}$ rated current main protection devices by one apartment are shown in figure 1 , but in single phase case with $20-32 \mathrm{~A}$ rated current main protection devices - in figure 2 .

In single phase main protection device case, equation (11) is replaced by $\sqrt{3} \cdot U_{\text {nom. }} \rightarrow U_{\text {nom.faze }}$.

Further recommendations are given for more frequently occurring design issues:

- if in a design there is shown separate apartments $\boldsymbol{P}_{\boldsymbol{m a x} . d z}$ and $\boldsymbol{I}_{a . d z .}$, then for incoming load estimation $\boldsymbol{P}_{\text {max. } . i v v .}$ : g

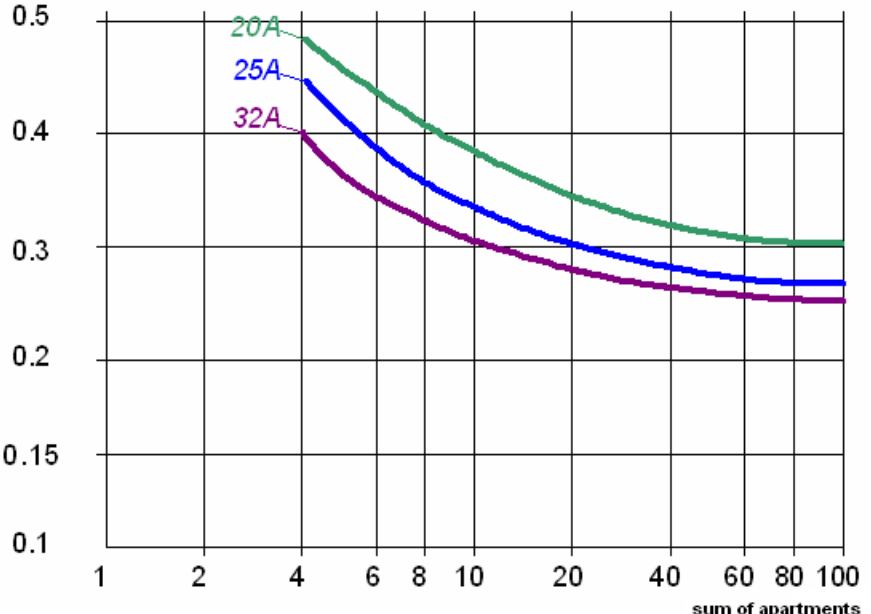

Fig. 2. The maximum simultaneous load factor of dwelling houses (single phase incoming line with rated current from 20 to $32 \mathrm{~A}$

- in approximate calculation, if sum of apartments $\boldsymbol{n}_{\boldsymbol{d z}}$. is more then 40 , using (2), there estimates incoming load for all dwelling house;

- in exact calculation, from figures 1 and 2 according to sum of apartments $\boldsymbol{n}_{\boldsymbol{d z}}$. and $\boldsymbol{I}_{\boldsymbol{a} . \boldsymbol{d z}}$, there estimates load simultaneous factor "g" and by (1) and (10) incoming load for all dwelling house;

- in cases, when variety rated currents $\boldsymbol{I}_{\boldsymbol{a} . d z}$. of apartments main protection devices is foreseen in a design, then load simultaneous factor " $\mathrm{g}$ " for separate current groups can be estimated by sum of apartments. Then by (10) load by groups is determinate and incoming load $\boldsymbol{P}_{\text {max.iev. }}$ is obtained by summing groups results.

if in a application calculated load $\boldsymbol{P}_{\text {max.iev. }}$ and sum of apartments $\boldsymbol{n}_{d z}$. is known, then for estimation $\boldsymbol{I}_{\boldsymbol{a} . \boldsymbol{d z} . .}$ :

- in approximate calculation, if sum of apartments $\boldsymbol{n}_{\boldsymbol{d z}}$. is more then 40, using (2), there estimates $\boldsymbol{P}_{\max . d z .}$, then from table I finds $\boldsymbol{I}_{a . d z .}$, which complies with allowed incoming load;

- in exact calculation, from figures 1 and 2 according to sum of apartments $\boldsymbol{n}_{\boldsymbol{d z}}$ and $\boldsymbol{I}_{\boldsymbol{a} . \boldsymbol{d} \boldsymbol{z}}$, there estimates load simultaneous factor "g" and by (1) and (10) maximal $\boldsymbol{I}_{a d z .}$ for one apartment, which complies with allowed incoming load.

- for checking fulfilling the development of incoming load, if sum of apartments $\boldsymbol{n}_{\boldsymbol{d z}}$. is known, then from (2) determines $\boldsymbol{P}_{\text {max.dz. }}$, which compares with values in table I.

Curves in figure 1 and 2 are used only in dwelling houses without electric heating and hot water.

\section{MANY-STORIED COMMERCIAL BUILDIGS}

Incoming load in commercial buildings is determined by total area of offices. In table III there is shown calculated loads by square meter depending on type of commercial building. 
Types of commercial buildings can divide as low load and high load commercial buildings. Value of low load is used in standard commercial buildings, but value of high load - in commercial buildings with communication (signal lines, TV, radio and the like) equipment. Incoming calculated load in commercial buildings is estimated by table III and (12)

$$
P_{\text {max.iev. }}=P_{\max . m 2 . b i r .} \cdot n_{m 2} \cdot
$$

where $\mathrm{P}_{\text {max.iev. }}$ - incoming calculated load in commercial buildings, $\mathrm{kW}$;

$\mathrm{P}_{\text {max.m2.bir. }}$ - specific calculated load per square meter $\mathrm{kW} / \mathrm{m}^{2}$;

$\mathrm{n}_{\mathrm{m} 2}-$ area in square meters.

TABLE III

ESTIMATION VALUES OF CALCULATED LOAD IN COMMERCIAL BUILDINGS

\begin{tabular}{|c|c|c|}
\hline 1 & 2 & 3 \\
\hline & Low load & High load \\
\hline$P_{\text {max.m2.bir. }}, \mathrm{W} / \mathrm{m}^{2}$ & 35 & 60 \\
\hline
\end{tabular}

\section{V.MANY-STORIED DWELLING HOUSE WITH OFFICES AND/OR SHOPS IN GROUND FLOORS}

Many-storied dwelling house with offices and/or shops in ground floors can be divided in two cases:

- in cases, when is known area of sum of apartments, offices and/or shops, calculated load can determine by sum of apartments load (in point III described methodology) and offices load (in point IV described methodology). This calculation can be considered as exact;

- in cases, when is not known exact area of offices and/or shops, but in known, what percentage of the area it will take, e.g., offices and shops will take up to $20 \%$ of the total area of building, then there should percentage increase apartments load (table IV).

TABLE IV

DWELLING HOUSES WITH OFFICES AND/OR SHOPS

\begin{tabular}{|c|c|}
\hline 1 & 2 \\
\hline$I_{a . d z, \mathrm{~A}}$ & $3 \times 16$ \\
\hline Proportion of offices or shops & $20 \%$ \\
\hline $\mathrm{n}_{\mathrm{dz} .}$ & $\geq 40$ \\
\hline$P_{\text {max.dz.+bir., }} \mathrm{kW} / \mathrm{dz}$. & 2.6 \\
\hline
\end{tabular}

Since in table III is specified load for house, where proportion of offices and/or shops is not exceeds $20 \%$, rated current of main protection device is $3 \times 16 \mathrm{~A}$ and sum of apartments is more then 40, incoming calculated current estimates using (13) and table III

$P_{\max . i e v .}=P_{\max . d z .+b i r .} \cdot n_{d z .}$.

where $\mathrm{P}_{\text {max.iev. }}$ - incoming load in commercial buildings, $\mathrm{kW}$;
$\mathrm{P}_{\text {max.dz.+bir. }}$ - apartments calculated load, taking into an account load of offices, $\mathrm{kW} / \mathrm{dz}$;

$\mathrm{n}_{\mathrm{dz} .}-$ sum of apartments.

\section{CONCLUSIONS}

Existing calculated load estimation methodology of electric power supply has to improve by adding now data of load inspections.

Many-storied dwelling houses and commercial buildings had inspected two years in every half an hour.

Methodology of calculated load estimation has actualized for many-storied dwelling houses, commercial buildings and many-storied dwelling houses with offices and/or shops in ground floors.

Load simultaneous factor "g" is physically established, estimation curves are compiled and their range of changes is described.

The methodology is not applicable in buildings with electric heating and hot water.

\section{REFERENCES}

[1] Gerhards J., Kozlova I., Lielpēteris E., Timmermanis K., Vanzovičs E., Elektroapgāde. Rīga: Zvaigzne, 1989.

[2] Vanags A., Elektriskie tīkli un sistēmas.. Rīga: RTU, 2002, pp. 479.

[3] Под ред. Д.А.Файбисовича, Справочник по проектированию электрических сетей. М.: НЦ ЭМАС, 2005.

[4] Baltiņš A., Kanbergs A., Miesniece S., Zemsprieguma elektriskie aparāti, R̄̄ga: Jumava, 2007.

[5] Timmermanis K., Aizsargslēeži un drošinātāji, Rīga: RTU, 2009.

[6] Instruktīvie materiāli, Metodika maksimālās vienlaicīgās slodzes noteikšanai daudzstāvu èku elektroapgādei, Latvenergo: Sadales tīkls, 2009.

[7] Budahs M., Vanzovičs E., Zviedrītis M., ,Jaunbūvējamo daudzdzīvokḷu māju elektroapgādes sistēmu slodzes noteikšana un aizsadzības aparātu izvēle," RTU Zinātniskie raksti, vol. 4, Enerğētika un elektrotehnika. Riga: RTU, 2010.

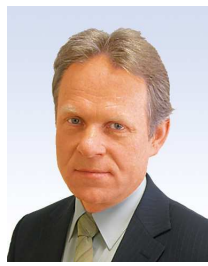

Martins Budahs, Research and Standard Department Leader, M. Sc. Ing.

Sadales tikls AS

Address: Smerla str., 1, LV-1006, Riga, Latvia.

Phone: +37167728314,

Email: Martins.Budahs@latvenergo.lv

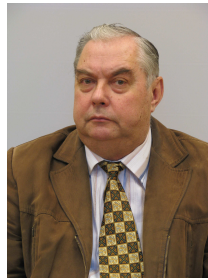

Edvins Vanzovichs, Professor, Dr..Sc.Ing.

Riga Technical University, Power Engineering Institute

Address: Kronvalda blv., 1, LV-1010, Riga, Latvia.

Phone: +3717089924 ,

Fax: +3717089905,

Email: vanzovic@eef.rtu.lv

Mareks Zviedritis, Research and Standards Department Engineer, M. Sc. Ing.

Sadales tikls AS

Address: Smerla str., 1, LV-1006, Riga, Latvia.

Phone: +37167728314.

Mareks.Zviedritis@latvenergo.lv 